\title{
Effects of udder infections with Staphylococcus xylosus and Staphylococcus warneri on the composition and physicochemical changes in cows milk
}

\author{
M. Vasil ${ }^{1}$, E. Pecka-Kiełb ${ }^{2}$, J. Elečko ${ }^{1}$, A. Zachwieja ${ }^{3}$, \\ W. Zawadzki ${ }^{2}$, F. Zigo' ${ }^{1}$, J. Illek ${ }^{4}$, Z. Farkašová ${ }^{1}$ \\ ${ }^{1}$ Department of Animal Breeding, University of Veterinary Medicine and Pharmacy, \\ Komenskeho 73, Kosice 041 81, Slovak Republic,
}

${ }^{2}$ Wroclaw University of Environmental and Life Sciences, Department of Biostructure and Animal Physiology, Norwida 31, 50-375 Wroclaw, Poland

${ }^{3}$ Wroclaw University of Environmental and Life Sciences, Department of Cattle Breeding and Milk Production, Chełmońskiego 38c, 51-630 Wrocław, Poland

${ }^{4}$ Clinical Laboratory for Large Animals, Faculty of Veterinary Medicine, University of Veterinary and Pharmaceutical Sciences, Brno, Czech Republic

\begin{abstract}
The aim of this study was an evaluation of the effects of two species of coagulase negative staphylococci (CNS), Staphylococcus xylosus and Staphylococcus warneri, on the changes in technological parameters of cows' milk. The study was conducted in a herd of Slovak Pied cattle breed (with share of HF blood). Based on the performance results from three subsequent months, cows in the $2^{\text {nd }}$ and $3^{\text {rd }}$ lactation with SCC up to 200 thousand/ml ( 8 heads, 32 quarters), and above 800 thousand/ml ( 8 heads, 32 quarters), after the $4^{\text {th }}$ month of lactation, were selected. The samples were subjected to microbiological analysis, total bacteria count, somatic cell count; basic milk composition and physicochemical properties were also examined. The research has found the impact of bacterial infection on the increasing $(\mathrm{p}<0.05)$ of the number of somatic cells and a decrease $(\mathrm{p}<0.01)$ in protein levels in milk due to both types of staphylococci. There was a significant $(\mathrm{p}<0.05)$ reduction in C8: 0 , C10: 0 and the total amount of saturated fatty acids in the milk of the infected cows in comparison to the healthy ones. The research also revealed higher $(\mathrm{p}<0.01)$ levels of $\mathrm{C} 14$ : 0 and $\mathrm{C} 20$ : 1 in milk from the healthy cows.
\end{abstract}

Key words: cows, milk, Staphylococcus xylosus, Staphylococcus warneri, physicochemical properties 


\section{Introduction}

Mastitis is the inflammatory reaction of the udder to invading pathogens which can be attributed to both clinical and subclinical forms of the disease - the most frequent and costly disease in dairy cattle (Halasa et al. 2007). Mastitis may be a result of an infection with various bacteria species, but Streptococcus and Staphylococcus strains are the main causes (Lidiane et al. 2012). Several bacterial species are considered major mastitis pathogens, including Staphylococcus aureus, Streptococcus agalactiae, resp. Streptococcus uberis and Escherichia coli. In recent years, the significance of CNS as causative agents of bovine subclinical mastitis has been well recognized (Taponen and Pyörälä 2009).

According to Awale et al. (2012), CNS is the most prevalent cause of subclinical mastitis. Cervinkova et al. (2013) reported that a total of 669 individual cow milk samples originating from asymptomatic cows from 16 dairy farms in the Czech Republic were examined for the presence of microorganisms with the potential to cause mastitis. Coagulase-negative staphylococci clearly predominated $(53.5 \%$ of positive samples) followed by streptococci and enterococci (both occurring in $16.1 \%$ of samples). In Finland, CNS were most frequently isolated from cows with mastitis, with the occurrence of CNS mastitis in $17 \%$ of examined quarters and above $50 \%$ in quarters with positive bacteriological findings (Kaliwal et al. 2011). In Norway, CNS were isolated from $3 \%$ of examined and $14 \%$ of bacteriologically positive quarters (Østerås et al. 2006). In one German study carried out in 80 herds of dairy cows, CNS were isolated from $9 \%$ to $35 \%$ of quarters (Tenhagen et al. 2006). Lim et al. (2007) recorded cases of CNS causing intramammary infections in dairy cows during the dry period. Vasil et al. (2012) reported that from of mastitis of dairy cows were recorded in Slovakia, around 17 species of staphylococci.

In their work, Sawant et al. (2009) reported that the most common species of CNS isolated from the samples of cows' milk and the surface of the mammary glands were: $S$. epidermidis, $S$. chromogenes, $S$. simulans, S. hyicus, S. xylosus and S. warneri. Their role as main pathogens in subclinical mastitis was revealed in several countries (Tenhagen et al. 2006, Lim et al. 2007, Pyörälä and Taponen 2009, Bochniarz et al. 2013).

Turkyilmaz and Kaya (2006) conducted a study which comprised 180 Staphylococcus spp. bacteria and concluded that CNS may be just as dangerous to animals as coagulase positive bacteria $(S$. aureus, $S$. hyicus and S. intermedius). Asymptomatic mastitis and the production of biofilm by some CNS species are important aspects of the long-term existence of CNS repositories in the body (Taponen et al. 2006, Rumi et al. 2013, Seixas et al. 2015).

Subclinical mastitis is the prevailing form of mastitis among cows, sheep and goats worldwide. The effect of CNS on milk yield (MY) is relatively minor, most likely due to compensation effect by the uninfected glands at the whole-cow level. However, the effect of ConS-induced subclinical mastitis on the quality of milk used for cheese production is significant and is reflected at the whole-cow level (Leitner et al. 2006, Pyörälä and Taponen 2009).

In milking ruminants with healthy udders, the content of protein, fat, carbohydrates, the share of protein fractions (including caseins) are the factors influencing biological and technological milk properties. These are determined both by genetic and environmental factors (Barłowska et al. 2012, Pecka et al. 2013).

Mastitis is accompanied by an increase in somatic cell count and by altering protein composition and the concentration of salts and lactose it may affect milk composition and its physicochemical and manufacturing properties, (Le Roux et al. 2003, Santos et al. 2004).

The aim of this study was to evaluate the effect of two coagulase negative species, Staphylococcus xylosus and Staphylococcus warneri, on the changes in technological parameters of cows' milk.

\section{Materials and Methods}

The study was conducted in a herd of Slovak Pied cattle breed (with a share of HF blood). The animals were housed in a free-stall system, and the basis of the cows' feed was TMR complete mixture. Their diet was formulated according to international standards (NRC, 2001). Milk samples were collected during milk yeld control from three subsequent months; cows in the $2^{\text {nd }}$ and $3^{\text {rd }}$ lactation with SCC up to 200 thousand/ml ( 8 heads, 32 quarters), and above 800 thousand $/ \mathrm{ml}$ ( 8 heads, 32 quarters), after the $4^{\text {th }}$ month of lactation, were selected. Milk samples were collected from selected animals from the quarter milking during evening milking into sterile containers, and they were transported to the laboratory at a temperature of $4^{\circ} \mathrm{C}$. Before milk collection, the udder was disinfected with $70 \%$ ethanol. Examined milk features were analyzed depending on the presence of coagulase negative staphylococci species. During the study all the animals were supervised by veterinarians. They had no symptoms of disease. 


\section{Microbiological examinations}

The obtained samples were subjected to microbiological examinations in order to determine the level of bacterial infection, and to distinguish the samples infected with Staphylococcus xylosus and Staphylococcus warneri, as well as non-infected samples. The following methodology was used: all isolates were characterized by classic microbiological methods, by primo-cultivation on 5\% blood agar and consistent cultivation on specific cultivation media. Based on the colony morphology, Staphylococcus spp. bacteria were selected for the tube coagulase test (Staphylo PK, Imuna-Pharm, Slovakia). Suspect coagulase negative colonies isolated from clinical cases of cows' mastitis (acute, subacute) were identified by two different methods: determining biochemical enzymatic properties of bacteria by STAPHYtest 24, with the TNW 7.0 identifying programme (Erba-Lachema, Brno, Czech Republic) whose precision of detection is over $90.0 \%$, and determining proteins spectrum with a Maldi-Biotyper (Bruker, USA) - scores in the range of 2.300-3.000 provide highly probable species identification. For the control of identification methods strains of Staphylococcus xylosus CCM 2738 and Staphylococcus warneri CCM 3730 obtained from the Czech Collection of Microorganisms were used (CCM, Masaryk University, Brno, Czech Republic).

\section{Analysis of physicochemical features of milk}

The content of fat, total protein, lactose and dry matter was determined in each sample using an Infrared Milk Analyzer 150 (Bentley Instruments Inc., Minnesota, USA). Somatic cell count (SCC) was analyzed using a Somacount 150 apparatus (Bentley Instruments Inc., Minnesota, USA), while total bacteria count (TBC CFU) was determined by cytometric method using a Bactocount 70 analyzer (Bentley Instruments Inc., Minnesota, USA). Active acidity was estimeted using a Level2 pH-meter (Hauptstz, Germany) according to the PN-A-86122standard, and potential acidity by the Soxhlet-Henkel method, the level of milk resistance on a Dramiński apparatus, density on a DMA 35N Density Meter (Montreal, Kanada), casein content using Walker's method according to PN-68/A-86122,1985 standard and while urea content on a CHEMSPEC (Ohio, USA) apparatus.

\section{Protein fractions share}

The share of protein fractions in the obtained samples was determined using Laemml's electrophor- esis (1970) on polyacrylamide gel in the presence of sodium dodecyl sulfate (SDS) according to the methodology described by Pecka et al. (2012).

\section{Fatty acids profile}

Fat present in the examined milk was extracted using Folch's method (Christie and William 1973). Methyl esters of fatty acids were obtained according to the method presented by Christopherson and Glass (1969). The fatty acids profile in obtained samples was determined using an Agilent Technologies 7890A gas chromatograph (California, USA) with FID detector. The identification of obtained fatty acids peaks was conducted by their comparison with retention times of fatty acids methyl esters standards (Sigma Aldrich).

\section{Statistical analysis}

The results of the study were elaborated statistically using one-factor analysis of variance ANOVA in Statistica 10.0 software. Significant differences were determined using Duncan's test. Significance was declared at $\mathrm{p}<0.05, \mathrm{p}<0.01$ and differences between means with $0.05<\mathrm{p}<0.10$ were accepted as representing tendencies.

\section{Results}

In the resulting trials $(n=64)$, the presence of Staphylococcus xylosus $(\mathrm{n}=16)$ and Staphylococcus warneri $(\mathrm{n}=14)$ was observed. Most examinations of milk gave negative results $(n=26)$. The effect of bacterial infection on the increase $(\mathrm{p}<0.05)$ in the level of somatic cells was determined (Table 1). Samples of milk infected with $S$. xylosus were characterized by the highest levels of SCC. Both types of staphylococci had an influence on the decrease of $(p<0.01)$ protein levels in milk. The lowest levels of protein, fat and dry matter as well as lowest level of caseins were obtained in trials where $S$. warneri were identified. There was no statistically significant impact of the presence of bacteria on the level of lactose in milk. The content of this sugar in each group was detected at approximately the same level. There was a slight increase in the level of urea in the infected milk in comparison to uninfected milk.

The premium protein fraction of healthy cows' milk differed slightly from the milk of the cows infected with $S$. xylosus and $S$. warneri (Table 2): in the milk of the infected cows, part h-casein was higher. The content of the IgG1 was similarly higher in the 
Table 1. Basic composition, urea level and cytological quality of cows' milk.

\begin{tabular}{cccccc}
\hline Parameter & $\begin{array}{c}\text { Uninfected } \\
(\mathrm{n}=26)\end{array}$ & $\begin{array}{c}\text { Staphylococcus } \\
\text { xylosus } \\
(\mathrm{n}=16)\end{array}$ & $\begin{array}{c}\text { Staphylococcus } \\
\text { warneri } \\
(\mathrm{n}=14)\end{array}$ & SEM & $P$ value \\
\hline SCC x 1000 $\cdot \mathrm{ml}^{-1}$ & $207.60^{\mathrm{a}}$ & $961.38^{\mathrm{b}}$ & 611.43 & 116.906 & 0.020 \\
TBC CFU x 1000 $\cdot \mathrm{ml}^{-1}$ ] & 185.68 & 1501.63 & 103.29 & 356.987 & 0.233 \\
Fat [\%] & 4.24 & 3.76 & 3.30 & 0.238 & 0.281 \\
Protein [\%] & $4.20^{\mathrm{Aa}}$ & $3.77^{\mathrm{b}}$ & $3.66^{\mathrm{B}}$ & 0.082 & 0.009 \\
Dry matter [\%] & $13.77^{\mathrm{b}}$ & 12.79 & $12.00^{\mathrm{a}}$ & 0.331 & 0.085 \\
Lactose [\%] & 4.68 & 4.64 & 4.47 & 0.059 & 0.360 \\
Casein [\%] & 3.17 & 2.95 & 3.13 & 0.081 & 0.496 \\
Urea [mg $\cdot \mathrm{ml}^{-1}$ ] & 362.35 & 391.76 & 388.89 & 14.446 & 0.633 \\
\hline
\end{tabular}

$\overline{a, b}-$ differences significant statistically $(\mathrm{p}<0.05) .{ }^{\mathrm{A}, \mathrm{B}}-$ differences statistically highly significant $(\mathrm{p}<0.01)$.

Table 2. Protein fractions share in cows' milk.

\begin{tabular}{cccccc}
\hline Parameter & $\begin{array}{c}\text { Uninfected } \\
(\mathrm{n}=26)\end{array}$ & $\begin{array}{c}\text { Staphylococcus } \\
\text { yylosus } \\
(\mathrm{n}=16)\end{array}$ & $\begin{array}{c}\text { Staphylococcus } \\
\text { warneri } \\
(\mathrm{n}=14)\end{array}$ & SEM & $P$ value \\
\hline$\alpha$-kasein [\%] & 25.89 & 26.77 & 28.20 & 1.486 & 0.821 \\
$\beta$-kasein [\%] & 13.60 & 13.67 & 13.26 & 0.732 & 0.977 \\
א-kasein [\%] & 14.82 & 14.61 & 15.63 & 0.973 & 0.922 \\
IgG1 [\%] & 12.95 & 14.57 & 13.67 & 0.901 & 0.798 \\
Serum albumin [\%] & 15.29 & 14.77 & 11.17 & 1.003 & 0.215 \\
$\alpha$-lactoalbumin [\%] & 9.95 & 10.54 & 9.08 & 0.565 & 0.645 \\
\hline
\end{tabular}

Table 3. Physicochemical properties of cows' milk.

\begin{tabular}{cccccc}
\hline Parameter & $\begin{array}{c}\text { Uninfected } \\
(\mathrm{n}=26)\end{array}$ & $\begin{array}{c}\text { Staphylococcus } \\
\text { xylosus } \\
(\mathrm{n}=16)\end{array}$ & $\begin{array}{c}\text { Staphylococcus } \\
\text { warneri } \\
(\mathrm{n}=14)\end{array}$ & SEM & $P$ value \\
\hline $\mathrm{pH}$ & $6.77^{\mathrm{a}}$ & $6.825^{\mathrm{Bb}}$ & $6.753^{\mathrm{A}}$ & 0.010 & 0.011 \\
Density $\left[\mathrm{g} / \mathrm{cm}^{3}\right]$ & 1.034 & 1.032 & 1.035 & 0.001 & 0.173 \\
Resistance $[\Omega]$ & 427.20 & 408.67 & 413.57 & 7.203 & 0.527 \\
${ }^{\circ} \mathrm{SH}$ & 9.39 & $8.63^{\mathrm{a}}$ & $9.95^{\mathrm{b}}$ & 0.242 & 0.103 \\
\hline
\end{tabular}

$\overline{a, b}$ - differences significant statistically $(\mathrm{p}<0.05)$. ${ }^{\mathrm{A}, \mathrm{B}}$ - differences statistically highly significant $(\mathrm{p}<0.01)$.

milk infected by $S$. xylosus: this fraction increased about $1.7 \%$, and in the group of $S$. warneri it increased by about $0.7 \%$ compared to the uninfected milk.

Compared to the milk of the healthy cows, the milk infected with $S$. warneri contained lower levels of $\beta$-casein, $\alpha$-lactoalbumin, serum albumin and higher $\kappa$-casein. The values of these fractions detected in the milk infected with S. xylosus were slightly different: the levels of $\kappa$-casein and serum albumin were lower, while the content of $\alpha$-lactoalbumin was higher. The differences between groups of samples were not significant.

The impact of infections $(\mathrm{p}<0.05)$ on $\mathrm{pH}$ value was reported in the analyzed trials (Table 3 ). The highest $\mathrm{pH}$ value was detected in the $S$. xylosus infection and the lowest in $S$. warneri. The value of $\mathrm{SH}$ was inversely proportional to the $\mathrm{pH}$ value. Differences in density between the infected milk and the milk of healthy cows were observed, while resistance was lower in the milk of cows infected by Staphylococcus spp.

There was a significant $(\mathrm{p}<0.05)$ reduction in the share of C8: 0, C10: 0 and the total amount of saturated fatty acids in the milk of the infected cows in comparison with the healthy animals (Table 4). Also, higher $(\mathrm{p}<0.01)$ levels of C14: 0 and C20: 1 in milk from the healthy cows were reported. Part of C17: 1, C20: 1, C18: 0 C18: 1n7t was at a higher level, and premium C6: 0; C18: 2n6c was lower compared to the milk of cows infected with $S$. xylosus and $S$ warneri. In the milk from the healthy cows, EPA content was higher $(\mathrm{p}<0.05)$ with about $0.02-0.03 \mathrm{~g} / 100 \mathrm{~g}$ of fat in relation to trials involving the milk of infected animals. Participation of C20: $4 \mathrm{n} 6$ in control milk remained at $0.59 \mathrm{~g} / 100 \mathrm{~g}$ of fat whereas in the milk of 
Table 4. Fatty acids profile of cows' milk.

\begin{tabular}{|c|c|c|c|c|c|}
\hline Parameter & $\begin{array}{l}\text { Uninfected } \\
\quad(n=26)\end{array}$ & $\begin{array}{c}\text { Staphylococcus } \\
\text { xylosus } \\
(\mathrm{n}=16)\end{array}$ & $\begin{array}{c}\text { Staphylococcus } \\
\text { warneri } \\
(\mathrm{n}=14)\end{array}$ & SEM & $P$ value \\
\hline $\mathrm{C} 4: 0^{1}$ & 0.76 & 0.40 & 0.59 & 0.075 & 0.121 \\
\hline $\mathrm{C} 6: 0^{1}$ & 0.92 & 0.66 & 0.68 & 0.055 & 0.069 \\
\hline $\mathrm{C} 8: 0^{1}$ & 0.79 & 0.65 & 0.63 & 0.028 & 0.039 \\
\hline $\mathrm{C} 10: 0^{1}$ & 2.29 & 2.07 & 1.91 & 0.061 & 0.032 \\
\hline $\mathrm{C} 12: 0^{1}$ & 3.14 & 2.97 & 2.75 & 0.075 & 0.118 \\
\hline $\mathrm{C} 13: 0^{1}$ & 0.10 & 0.11 & 0.09 & 0.004 & 0.162 \\
\hline $\mathrm{C} 14: 0^{1}$ & 11.39 & 10.95 & 9.99 & 0.176 & 0.005 \\
\hline $\mathrm{C} 15: 0^{1}$ & 1.30 & 1.38 & 1.32 & 0.022 & 0.359 \\
\hline $\mathrm{C} 16: 0^{1}$ & 33.63 & 32.77 & 31.17 & 0.551 & 0.210 \\
\hline $\mathrm{C} 17: 0^{1}$ & 0.59 & 0.61 & 0.65 & $0.0^{1} 6$ & 0.337 \\
\hline $\mathrm{C} 18: 0^{1}$ & 7.54 & 7.20 & 8.56 & 0.237 & 0.093 \\
\hline $\mathrm{C} 20: 0^{1}$ & 0.15 & 0.16 & 0.18 & 0.006 & 0.081 \\
\hline$\Sigma$ SFA & 62.55 & 59.93 & 58.49 & 0.693 & 0.045 \\
\hline $\mathrm{C} 14: 1^{1}$ & 1.12 & 0.93 & 0.92 & 0.048 & 0.144 \\
\hline $\mathrm{C} 15: 1^{1}$ & $0.21^{\mathrm{a}}$ & 0.23 & $0.22^{\mathrm{b}}$ & 0.001 & 0.827 \\
\hline $\mathrm{C} 16: 1^{1}$ & 7.12 & 7.19 & 7.14 & 0.584 & 0.999 \\
\hline $\mathrm{C} 17: 1^{1}$ & 0.27 & 0.33 & 0.36 & 0.015 & 0.053 \\
\hline $\mathrm{C} 18: 1 \mathrm{n} 9 \mathrm{c}^{1}$ & 17.12 & 17.07 & 17.01 & 0.279 & 0.989 \\
\hline $\mathrm{C} 18: 1 \mathrm{n} 7 \mathrm{t}^{1}$ & 1.20 & 1.27 & 1.55 & 0.075 & 0.078 \\
\hline $\mathrm{C} 18: 1 \mathrm{t}^{1}$ & 0.69 & 0.69 & 0.80 & 0.064 & 0.166 \\
\hline $\mathrm{C} 18: 2 \mathrm{n} 6 \mathrm{c}^{1}$ & 1.34 & 1.28 & 1.16 & 0.033 & 0.087 \\
\hline $\mathrm{C} 18: 2 \mathrm{n} 6 \mathrm{t}^{1}$ & 1.84 & 2.50 & 2.67 & 0.175 & 0.102 \\
\hline $\mathrm{C} 18: 3 \mathrm{n} 3^{1}$ & 0.47 & 0.49 & 0.50 & 0.025 & 0.146 \\
\hline $\mathrm{C} 20: 1^{1}$ & 0.22 & 0.17 & 0.18 & 0.011 & 0.002 \\
\hline $\mathrm{C} 20: 4 \mathrm{n} 6^{1}$ & 0.59 & 0.11 & 0.41 & 0.185 & 0.541 \\
\hline $\mathrm{CLA}^{1}$ & 0.55 & 0.61 & 0.57 & 0.019 & 0.393 \\
\hline EPA $^{1}$ & 0.08 & 0.06 & 0.05 & 0.005 & 0.032 \\
\hline$\Sigma$ UFA & 32.58 & 33.56 & 33.75 & 0.603 & 0.928 \\
\hline
\end{tabular}

${ }^{1} \mathrm{~g} / 100 \mathrm{~g}$ fat

$\mathrm{a,b}$ - differences significant statistically $(\mathrm{p}<0.05)$. ${ }^{\mathrm{A}, \mathrm{B}}$ - differences statistically highly significant $(\mathrm{p}<0.01)$.

cows infected with $S$. xylosus, and $S$. warneri acid content was lower by as much as $0.48 \mathrm{~g} / 100 \mathrm{~g}$ and 0.18 $\mathrm{g} / 100 \mathrm{~g}$ of fat. The inverse relationship was noted in acid C18: 2n6t, and the growth in S. xylosus $0.66 \mathrm{~g} / 100$ $\mathrm{g}$ and $S$. warneri $0.83 \mathrm{~g} / 100 \mathrm{~g}$ in relation to milk from the healthy cows.

\section{Discussion}

An increase in the number of pathogenic bacteria in milk is accompanied by a higher somatic cell count, which is considered as a determinant of cow mammary gland health (Harmon 2001, Santos et al. 2004, Lidiane et al. 2012, Bortolami et al. 2015). These results are consistent with those obtained in our study. We found that the bacterial infection significantly increased the level of somatic cells $(\mathrm{p}<0.05)$.

In their work, Coulon et al. (2002) note that Staphylococci were the most frequently isolated germs (Staphylococcus aureus: 27\%, CNS: 26\%, Streptococci: 21\%). Major milk pathogens (Staphylococcus aureus, Streptococcus uberis or Escherichia coli) associated with clinical signs of mastitis were accompanied by higher SCC $\left(+1.6 \log \cdot \mathrm{ml}^{-1}, \mathrm{p}<0.01\right)$, lower lactose concentration $\left(-7.6 \mathrm{~g} \cdot \mathrm{kg}^{-1}, \mathrm{p}<0.01\right)$ and higher protein concentration $\left(+3.3 \mathrm{~g} \cdot \mathrm{kg}^{-1}, \mathrm{p}<0.01\right)$; hence a sharp decrease in the casein/protein ratio $(-10$ percentage points, $\mathrm{p}<0.01)$. While $\mathrm{CNS}$ slightly reduced lactose concentration $\left(-1.8 \mathrm{~g} \cdot \mathrm{kg}^{-1}\right)$, they also increased SCC $\left(+0.37 \log \cdot \mathrm{ml}^{-1}\right)$. This study demonstrated the decreasing effect of $S$. xylosus and S. warneri on the protein and dry matter levels and no effects on lactose and fat levels, which may suggest the negative effect the bacteria have on these milk parameters.

Malek dos Reis et al. (2013) as well as other authors state that subclinical mastitis reduced lactose, nonfat solids and total solids content, but no difference was found in the protein and fat content between infected and uninfected quarters. Seasonality influenced milk composition both in mammary quarters and composite milk samples. Leitner et al. (2011) add that casein-derived peptides serve as negative-feedback control of milk secretion by limit- 
ing lactose secretion also involved in impeding casein coagulation.

The variation in biochemical composition and technological properties of milk and dairy products has several origins: animal diet, genetic factors and milk cold storage (Le Roux et al. 2003). Milk composition is also known to be highly dependent on the animals' health status, especially on mammary gland health (Ogola et al. 2007). Milk fat and protein rates are modified by bacterial intramammary infections (IMI) (Seegers et al. 2003). It is also known that negative energy balance and protein imbalances decrease the animal immune defense. Disturbance in the metabolism may lead to the accumulation of fat in the liver, decreasing the functional capacity of the immune system, favoring the onset of mastitis (Pyörälä 2008). Urea level in cows' milk mainly depends on their nutrition (Godden et al. 2001, Lehloenya et al. 2008). Other authors did not observe an effect of somatic cell count, and thus mammary gland status, or on milk urea level (Henao-Velásquez et al. 2014). Mammary gland inflammation, caused by CNS can cause financial losses not only as concerns milk production, but milk quality as well. In milk samples examined in this study, bacterial infection resulted in an increase in urea share.

Milk protein substances include whey proteins and $\alpha \mathrm{s}_{1}, \alpha \mathrm{s}_{2}, \beta, \kappa$ and $\gamma$-casein proteins. From the technological point of view, the most desirable is milk with a high content of $\kappa$-casein, due to its improved technological parameters and processing usefulness (Varhimo et al. 2011, Pecka et al. 2013). A greater permeability of blood-milk barrier during the inflammation results in an easier transfer of serum proteins and blood enzymes, which may lead to an increased proteolysis of milk proteins (Forsbáck et al. 2010). Proteolysis of caseins in milk related to bacterial infections leads to a decrease in the share of $\alpha$ - and $\beta$ - casein (Leitner et al. 2006, Hamed al. 2012). The results obtained in this study also correspond well with the studies of other authors who noted a positive relationship between casein level in milk and CNS (Coulon et al. 2002).

A reduction in serum albumin content in the samples infected with $S$. xylosus and $S$. warneri was noted, which confirms an earlier study which demonstrated a decrease in serum albumin level with SCC increase (Zielak-Steciwko et al. 2014). But Coulon et al. (2002) demonstrated that CNS infections are responsible for an increase in IgG in the udder from 0.60 to $0.64 \mathrm{~g} / \mathrm{kg}$ and they also caused an increase in the share of serum albumin from 0.17 to $0.19 \mathrm{~g} / \mathrm{kg}$. Our results are consistent only with those concerning IgG1; the value of the share of serum albumin in our study was reduced.
The results of this study suggest that the mastitis caused by $S$. xylosus and $S$. warneri affects the composition of milk. Pyörät (2003) accounts for the possible differneces. It apparent that the degree of change depends on the severity of the inflammatory response, the amount of the affected tissue of the mammary glands and the pathogenicity and the virulence factors of the bacteria.

The value of $\mathrm{pH}$ should be in the range from 6.6 to 6.8 (Batavani et al. 2007, Fulya 2011). Milk density is a resultant of the components contained in it, and ranges from 1.023 to $1.040 \mathrm{~g} / \mathrm{dm}^{3}$ (Park et al. 2007). Similar parameters were obtained in the present study.

The results of our earlier research on milk showed no effect of Streptococcus uberis on density, resistance and SH value (Pecka-Kiełb et al. 2016). There was also no effect of bacterial infection with Staphylococcus xylosus and Staphylococcus warneri on the density, resistance and SH milk. Consequently, subclinical mastitis affects the synthesis process of cow fatty acids and changes the composition of fatty acids. Mammary gland secretion derived from cows in a subclinical inflammation state is characterized by a reduced share of long-chain unsaturated fatty acids and an increased content of saturated acids (Chang et al. 2011). Increased levels of the majority of functional FAs and FA groups, and higher values of their ratios were noted in milk containing more than 400,000 somatic cells per ml, which could be indicative of mastitis (Sobczuk-Szul et al. 2015). Our research showed only changes in EPA and C20:1. The levels of these acids in milk coming from infected cows were lower.

\section{Conclusion}

In this study the effects of two species of CNS on the changes in technological parameters of cows' milk were studied. The results demonstrated the decreasing effect of $S$. xylosus and $S$. warneri infection on the level of protein and dry matter, and no effects on lactose and fat, which may be evidence of the negative effect of these bacteria on the aforementioned milk parameters. In this study we found that the bacteria causing subclinical mastitis increased the level of somatic cells and that the urea share was subject to an increase affected by the bacterial infection.

\section{Acknowledgements}

This study was supported by project APVV-0679-10 and project VEGA-1/0510/16 (Slovak). 


\section{References}

Awale MM, Dudhatra GB, Kumar A, Chauhan BN, Kamani DR, Modi CM, Patel HB, Mody SK (2012) Bovine mastitis: a threat to economy. Open Access Scientific Reports 1: 295.

Barłowska J, Litwińczuk Z, Brodziak A, Chabuz W (2012) Effect of the production season on nutritional value and technological suitability of milk obtained from intensive (TMR) and Traditional Feeding system of cows. J Microbiol Biotech Food Sci 1: 1205-1220.

Bortolami A, Fiore E, Gianesella M, Corro M, Catania S, Morgante M (2015) Evaluation of the udder health status in subclinical mastitis affected dairy cows through bacteriological culture, somatic cell count and thermographic imaging. Pol J Vet Sci 18: 799-805.

Batavani RA, Asri S, Naebzadeh H (2007) The effect of subclinical mastitis on milk composition in dairy cows. Iran J Vet Res 8: 205-211.

Bochniarz M, Wawron W, Szczubial M (2013) Coagulase-negative staphylococci (CNS) as an aetiological factor of mastitis in cows. Pol J Vet Sci 16: 487-492.

Cervinkova D, Vlkova H, Borodacova I, Makovcova J, Babak V, Lorencova A, Vrtkova I, Marosevic D, Jaglic $\mathrm{Z}$ (2013) Prevalence of mastitis pathogens in milk from clinically healthy cows. Vet Med 58: 567-575.

Chang L, Yang Z, Wu H, Chen Y, Shi X, Mao Y, Cen N, Liang $X$, Yin $Z$ (2011) Comparative Study on Fatty Acid Composition between Normal Milk and Subclinical Mastitis Milk of Dairy Cow. Acta Vet et Zoot Sinica 42: 44-47.

Christie W, William S (1973) Lipid analysis. Isolation, separation, identification and structural analysis of lipids. The isolation of lipids from tissues. Pergamon Press, Oxford pp 39-40.

Christopherson SW, Glass RL (1969) Preparation of milk fat methyl esters by alcoholysis in an essentially nonalcoholic solution. J Dairy Sci 52: 1289-1290.

Coulon JB, Gasqui P, Barnouin J, Ollier A, Pradel P, Pomiès $D$ (2002) Effect of mastitis and related-germ on milk yield and composition during naturally-occurring udder infections in dairy cows. Anim Res 51: 383-393.

Forsbäck L, Lindmark-Mansson H, Andren A, Svennersten-Sjaunja K (2010) Evaluation of quality changes in udder quarter milk from cows with low-to-moderate somatic cell counts. Animal 4: 617-626.

Fulya T (2011) Microbiological and Chemical Properties of Raw Milk Consumed in Burdur. J Anim Vet Adv 10: 635-641.

Godden SM, Lissemore KD, Kelton DF, Leslie KE, Walton JS, Lumsden JH (2001) Factors associated with milk urea concentration in Ontario dairy cows. J Dairy Sci 84: $107-114$

Halasa T, Huijps K, Osteras O, Hogeveen H (2007) Eco-nomic effects of bovine mastitis and mastitis manage-ment: a review. Vet Q 29: 18-31.

Hamed, H, Truijllo AJ, Juan B, Guamis B, ElFeki A, Gargouri A (2012) Interrelationships between somatic cell counts, lactation stage and lactation number and their influence on plasmin activity and protein fraction distribution in dromedary (Camelus dromedaries) and cow milks. Small Ruminant Res 105: 300-307.

Harmon RJ. (2001) Somatic cell counts: A primer. Madison to Reno, National Mastitis Council Annual Meeting Proceedings pp 3-9.
Henao-Velásquez AF, Mxnera-Bedoya OD, Herrera AC, Agudelo-Trujillo JH, Cerón-Munoz MF (2014) Lactose and milk urea nitrogen: fluctuations during lactation in Holstein cows. R Bras Zootec 43: 479-484.

Kaliwal BB, Sadashiv SO, Kurjogi MM, Sanakal RD (2011) Prevalence and antimicrobial susceptibility of coagulase-negative staphylococci isolated from bovine mastitis. Vet World 4: 158-161.

Laemmli UK (1970) Cleavage of structural proteins during the assembly of the head of bacteriophage T4. Nature 227: 680-685.

Lehloenya KV, Stein DR, Allen DT, Selk GE, Jones DA, Aleman MM, Rehberger TG, Mertz KJ, Spicer LJ (2008) Effects of feeding yeast and propionibacteria to dairy cows on milk yield and components, and reproduction. J Anim Physiol Anim Nutr (Berl) 92: 190-202.

Leitner G, Krifucks O, Merin U, Lavi Y, Silanikove $\mathrm{N}$ (2006) Interactions between bacteria type, proteolysis of casein and physico-chemical properties of bovine milk. Int Dairy J 16: 648-654.

Leitner G, Merin U, Silanikove N (2011) Effects of glandular bacterial infection and stage of lactation on milk clotting parameters: comparison among cows, goats and sheep. Int Dairy J 21: 279-285.

Le Roux Y, Laurent F, Moussaoui F (2003) Polymorphonuclear proteolytic activity and milk composition change. Vet Res 34: 629-645.

Lidiane CS, Pereira IA, Pribul BR, Oliva MS, Coelho SM, Souza MM (2012) Antimicrobial resistance and detection of mecA and bla $\mathrm{Z}$ genes in coagulase-negative Staphylococcus isolated from bovine mastitis. Pesq Vet Bras 32: 692-696.

Lim GH, Leslie KE, Kelton DF, Duffield TF, Timms LL, Dingwell RT (2007) Adherence and efficacy of an external teat sealant to prevent new intramammary infections in the dry period. J Dairy Sci 90: 1289-1300.

Malek dos Reis CB, Barreiro JR, Mestieri L, Porcionato MA, dos Santos MV (2013) Effect of somatic cell count and mastitis pathogens on milk composition in Gyr cows. BMC Vet Res 9: 67.

Ogola H, Shitandi A, Nanua J (2007) Effect of mastitis on raw milk compositional quality. J Vet Sci 8: 237-242.

Østerås O, Szlverzd L, Reksen O (2006) Milk Culture Results in a Large Norwegian Survey - Effects of Season, Parity, Days in Milk, Resistance and Clustering. J Dairy Sci 89: 1010-1023.

Park YW, Juárez M, Ramos M, Haenlein GF (2007) Physico-chemical characteristics of goat and sheep milk. Small Ruminant Res 68: 88-113.

Pecka E, Dobrzański Z, Zachwieja A, Szulc T, Czyż K (2012) Studies of composition and major protein level in milk and colostrum of mares. Anim Sci J 83: 162-168.

Pecka E, Zachwieja A, Tumanowicz J (2013) Technological parameters of milk depending onthe cow housing system, nutrition system, age and number of somatic cells. Przemysł Chemiczny 92: 1087-1091.

Pecka-Kiełb E, Vasil M, Zachwieja A, Zawadzki W, Elečko J, Zigo F, Illek J, Farkašova Z (2016) An effect of mammary gland infection caused by Streptococcus uberis on composition and physicochemical changes of cows' milk. Pol J Vet Sci 19: 49-55.

Pyörälä S (2008) Mastitis in post-partum dairy cows. Reprod Domest Anim 43 (Suppl 2): 252-259. 
Pyörälä S, Taponen S (2009) Coagulase-negative staphylococci-emerging mastitis pathogens. Vet Microbiol 134: 3-8.

Pyörälä S (2003) Indicators of inflammation in the diagnosis of mastitis. Vet Res 34: 565-578.

Rumi MV, Huguet MJ, Bentancor AB, Gentilini ER (2013) The icaA gene in staphylococci from bovine mastitis. J Infect Dev Ctries 7: 556-560.

Santos JE, Cerri RL, Ballou MA, Higginbotham GE, Kirk JH (2004) Effect of timing of first clinical mastitis occurrence on lactational and reproductive performance of Holstein dairy cows. Anim Reprod Sci 80: 31-45.

Sawant AA, Gillespie BE, Oliver SP (2009) Antimicrobial susceptibility of coagulase- negative Staphylococcus species isolated from bovine milk. Vet Microbiol 134: 73-81.

Seegers H, Fourichon C, Beaudeau F (2003) Production effects related to mastitis and mastitis economics in dairy cattle herds. Vet Res 34: 475-491.

Seixas R, Varanda D, Bexiga R, Tavares L, Oliveira M (2015) Biofilm-formation by Staphylococcus aureus and Staphylococcus epidermidis isolated from subclinical mastitis in conditions mimicking the udder environment. Pol J Vet Sci 18: 787-792.

Sobczuk-Szul M, Wielgosz-Groth Z, Nogalski Z, Mochon M, Rzemieniewski A, Pogorzelska-Przybyłek P (2015). Changes in the fatty acid profile of cow's milk with different somatic cell counts during lactation. Vet Med Zoot 69: 52-57.

Taponen S, Pyörälä S (2009) Coagulase-negative staph-ylococci as cause of bovine mastitis-not so different from Staphylococcus aureus? Vet Microbiol 134: 29-36.
Taponen S, Simojoki H, Haveri M, Larsen HD, Pyörälä $S$ (2006) Clinical characteristics and persistence of bovine mastitis caused by different species of coagulase-negative staphylococci identified with API or AFLP. Vet Microbiol 115: 199-207.

Tenhagen BA, Koster G, Wallmann J, Heuwieser W (2006) Prevalence of mastitis pathogens and their resistance against antimicrobial agents in dairy cows in Brandenburg, Germany. J Dairy Sci 89: 2542-2551.

Türkyilmaz S, Kaya O (2006) Determination of some Virulence Factors in Staphylococcus Spp. Isolated from Various Clinical Samples. Turk J Vet Anim Sci 30: $127-132$.

Varhimo E, Varmanen P, Fallarero A, Skogman M, Pyörälä S, Livanainen A, Sukura A, Vuorela P, Savijoki K (2011) Alpha- and $\beta$-casein components of host milk induce biofilm formation in the mastitis bacterium Streptococcus uberis. Vet Microbiol 149: 381-389.

Vasil M, Elečko J, Zigo F, Farkašová Z (2012) Occurrence of some pathogenity factors in coagulase negative staphylococci isolated from mastitis milk in dairy cows. Potravinarstvo 6: 60-63.

Zielak-Steciwko A, Pecka E, Kęsek M, Kuczaj M, Szulc $\mathrm{T}$ (2014) Changes in the proportion of proteins fractions depending on lactoferrin polymorphism gene and the somatic Cells Count in the milk of Polish Holstein-Frisian and Polish Red-White cattle. Vet Med Zoot 88: $83-89$. 